Vesna P. CIDILKO*

Humboldt Universität zu Berlin Berlin
Оригинални научни рад

Примљен: 08.11.2019.

Прихваћен: 12.02.2020.

\title{
ПРОЗА ГОРАНА ПЕТРОВИЋА И ЛЕКСИКОГРАФСКО-ЕНЦИКЛОПЕДИЈСКА ПАРАДИГМА У СРПСКОЈ КЮИЖЕВНОСТИ
}

Књижевно стваралаштво Горана Петровића показује низ фасета које овог савременог писца карактеришу као представника једне одређене епохе српске књижевности, али и као стваралачку индивидуалност са различитим развојним фазама. Један од елемената наративне структуре пре свега Петровићевих прича и есејистичких текстова дотиче се и енциклопедијске парадигме која као тежња ка свеобухватности има дугу традицију у српској књижевности. У излагању ће се на примерима из старије и новије прозе покушати дати увид у овај наративни слој књижевног текста и његову функцију у конкретном жанровском остварењу аутора.

Кључне речи: лексикографска парадигма, енциклопедијски наративни захват, аутопоетички текст, адитивна форма књижевног енциклопедизма.

\section{I. Уводне напомене}

За лексикографску парадигму у новијој српској прози везана су имена Данила Киша, Борислава Пекића, Милорада Павића, Светислава Басаре. Овом списку може се додати и Горан Петровић. Код наведених аутора енциклопедијски наративни захват по правилу своје упориште има у оквирима постмодернизма, док је примарни жанр у овом контексту како знамо роман. Текст изграђен по принципима лексикографског кода карактеристичан је пре свега за Петровићеве краће прозне форме, којима ћемо се у првом реду у даљем излагању бавити. ${ }^{1}$

*vesna.cidilko@staff.hu-berlin.de

${ }^{1}$ Повезаност кратких приповедних форми и романа представља једну од карактеристика Петровићеве прозе, како то показује генеза аутореве „кино-новеле” „Испод таванице која се љуспа” и 2006. у збирци „Разлике” објављене истоимене приче. Најпознатији Петровићев роман „Опсада цркве Светог Спаса” повезан је са низом ауторових прича, на шта упућује Александар Дунђерин: „Горан Петровић је књижевник који из књиге у књигу преноси одређене мотиве, чак и варијације читавих реченица, лајтмотива, пасажа. Тако су делови 'Атласа описаног небом' и 


\section{II. Приповедни свет Горана Петровића и интегралистичка визија нарације}

Поменути наративни захват није ограничен на ауторе једног одређеног књижевног правца. Тако по мишљењу неких критичара роман „Тесла, портрет међу маскама” Владимира Пиштала има енциклопедијски карактер (Гвозденовић 2017). Приповетка Александра Тишме „Човек у млечном ресторану” почиње реченицом „Један човек брише са лица мрве хране.” (Тишма 1980: 11) која причу на први поглед смешта ван времена и простора. Овај шкрти почетак, међутим, уводи читаоца у нешто што тежи да буде свеобухватна слика једног момента људске егзистенције, једне животне сцене - осветљене до најмањих детаља, захваљујући пажљивом и свезнајућем приповедачу, енциклопедијске упућености које читалац постаје свестан како се ближи крај приче. Густо плетено ткиво универзалног увида у живот и свет одражава се и формално: прича се састоји из само два, по обиму неједнака пасуса - непуна три реда заузима други, закључни, ${ }^{2}$ док се први простире на преко четири претходне странице књиге, попут детаљне енциклопедијске или речничке одреднице. И у причи „На краткој вожњи” аутор се користи сличним захватом стварајући неку врсту „лексиконског пописа” путника дунавске лађе, са тенденцијом ка свеобухватности описаног (Тишма 1980: 64).

Потпуно или делимично изведену ову наративну парадигму налазимо и код Горана Петровића. Тематизовање поетичких механизама енциклопедијског модела прозе у основи је „Приче о причању” којом започиње збирка „Све што знам о времену”:

Bepyje се [...] да је некада давно постојао некакав кнез који [...] је страсно премеравао све што је поседовао [...]. Лично је, каже повест, пребројао и пописао сваку длачицу у веђама своје лепе жене, сваки одсјај у њеним очима, сваки њен уздах, па онда сваки драги камен, сваки жежени дукат, напослетку и сваку бакрену парицу у угловима ризнице [...] Одужили су се пописи кнежеве имовине, највећа соба у двору беше одређена за књиге и свитке, а нешто мања за спискове тих књига и свитака, док је трећа служила за спискове спискова (Петровић 2004: 5-6).

Овај аутопоетички текст нека је врста увода у оно што следи - тежња ка свеобухватности постаје основни принцип сагледавања света. Интегралистичка визија примарно одређује структуру текста, при чему се може говорити о типу који има облик означен као меморабилија (од лат. memorabilia) и који представља архаични поетски модел поједностављене структуре (Мецлер 2007: 489), а ослања се на легенду, сагу, мит или бајку, што се у Петровићевом тексту јасно види из приповедног дуктуса. Већина примера енциклопедијске парадигме у причама овога аутора припада такозваној адитивној

\footnotetext{
'Острва и околних прича' уткани у ткиво 'Опсаде цркве Светог Спаса', а делови 'Опсаде' лирски сажимани у 'Ближњима'” (Дунђерин 2010). За разлику од Дунђерина који у томе види знаке стваралачке кризе, не упуштамо се у вредновање овог наративног захвата аутора.

${ }^{2}$ Тишма 1980: 15 .
} 
форми књижевног енциклопедизма ${ }^{3}$ која је код њега превасходно заступљена и која је уско повезана са једном од одлика постмодернистичке поетике, наиме набрајањем. Код Горана Петровића налазимо га у мање или више израженом облику у свим текстовима раних збирки. У „Саветима за лакши живот" срећемо се са примерима ексесивне примене овог поступка при чему се целокупан текст састоји искључиво од набрајања. ${ }^{4}$ Примера има још. Део приче „Све што знам о времену” под насловом „Три” састоји се скоро у целини од минуциозне листе улазница, карти, музејских проспеката донетих са пута у Франкфурт на Мајни, дугачак списак се закључује изјавом приповедача да је све те „штампане доказе” свог кретања сакупљао „углавном имајући на уму да ће ми кад-тад користити при састављању прича" (Петровић 2004: 208-209). Енциклопедијска свеобухватност слике света основа је и уметничке транспозиције стварности у нарацију. Као у „Причи о причању” и овде налазимо аутопоетичке сегменте, уско повезане са примењеним наративним моделом. Да је у причи „Из хронике тајног друштва” реч о енциклопедијском архивирању, а не просто набрајању сведочи реченица приповедача „Нисам стизао све да запишем" (Петровић 2004: 78). Сврха свега је, наиме, настанак хронике, хронике дешавања, за коју је по природи ствари задужен песник, приповедач и која је свеобухватног карактера, бележи се све до најмањег детаља:

Ја сам, дабоме, седео на церовом пању и на коленима писао Хронику овог сусрета, трудећи се да забележим све како се дешава, закључно са једним лептиром, што се на папир спустио крајем истог поглавља (Петровић 2004: 78).

У текстовима раних збирки доминира очуђење и апсурдно, захваљујући неочекиваним, онеобичавајућим мотивима и пре свега неконвенционалним лексичким комбинацијама. Тако је у поменутој причи реч о хвату мрака као количинској али и временској одредници, мада је хват стара мера за дужину (Петровић 2004: 74, 79), мирису боја и терпентина додаје се обрис ${ }^{5}$ свечаности (Петровић 2004: 77) који у овој причи претходи излету, уласку књижевних ликова (приповедач песник, његова супруга, музичарка, глумац и сликар) у слику, у насликан пејзаж. Укидање границе између сна и јаве, стварног и фантастичног онеобичава текст, ${ }^{6}$ који иначе код Петровића није строго формално организован по принципу лексикографског штива, ${ }^{7}$ како то налазимо

\footnotetext{
3 За разлику од интегративне која подразумева преструктурисање у нов поредак, ред ствари или појава, иначе обе познате још од антике (Мецлер 2007: 192).

${ }^{4}$ На пример у тексту „Шта се убраја у невероватне доживљаје” (Петровић 2004: 15-16). Слободанка Шаренац у овом контексту упућује на систематичност листе невероватних доживљаја, чиме се по њеном мишљењу открива и природа фантастичног доживљаја самог (Шаренац 2016: 67), дакле као у енциклопедијској одредници. Шареновић иначе у својој дисертацији нигде експлицитно не говори о лексикографској парадигми.

${ }^{5}$ Подвукла В. Ц.

${ }^{6}$ Слободанка Шаренац овде упућује на егзистентност уметничког света који се ставља у исту раван са стварношћу (Шаренац 2016: 220).

${ }^{7}$ Принцип лексиконског структурисања постоји у зачетку, мисли се на коришћење бројева за означавање делова текста. Сличну улогу имају и обавезни „поднаслови” којима су означени поједини делови прича, при чему се у овом случају може говорити и о архаизацији преузимањем узуса који је некада био често коришћен у главама романа на пример.
} 
код неких од горе побројаних аутора. ${ }^{8}$ Тако се на другом месту срећемо са буквално нанизаним речима, радиом који емитује ћутање и крешендо тишине (Петровић 2004: 81). Да се ради о енциклопедијском принципу, о архивирању и архиви а не гомили речи без икаквог реда, показује чињеница да су пред нама семантички кохерентне групе нанизаних, сакупљених или из лексичког обиља издвојених речи: необична огрлица коју тајанствена жена у „Речима” носи састоји се од нанизаних лексема БЛЕСАК, СЈАJ, СЈАЈАК, СВЕТЛУК (Петровић 2004: 82), да наведемо само један пример. Прича тематизује чудесни свет речи, па се тако говори и о речницима који су и овде, али буквално, складишта, архиви језичког блага:

Соба је била препуна књига. [...] Били су то сами речници. Стотине речника. Велики и мали, џепни, у неколико томова, меких корица, повезани у кожу, домаћи и инострани, општи и посебни, од неких и по више издања [...]. (Петровић 2004: 85-86).

Поигравање са смислом, са конвенционалним наративним захватима, језички и стилски експерименти у форми постмодернистичке деструкције стварносних модела једна су од одлика ране прозе Горана Петровића. Неконвенционална еротска сцена која дословно настаје од речи доказује да речи, сведене на суштинско свог значења не служе искључиво за опис или комуникацију већ и стварају свет. ${ }^{9}$ Градска врева у коју приповедач излази из омамљујуће тишине је огромна, а чине је трице гласова, прозукли одломци разговора, жижљиве говоранције, велика обећања, бескрајне жалопојке, нападне хвале, ништавне клетве, отужна умиљавања, која допиру до приповедача, прсе се, отежу, јече, развлаче се или једноставно успевају (Петровић 2004: 87). До онеобичавања доводи искључива употреба персонификације која се реализује кроз глагол, док су атрибути у принципу конвенционалне природе. ${ }^{10}$

\section{III. Енциклопедија и феномен палимпсеста или скроман простор на спруду живљења}

У једном од текстова, насловљеном са „На спруду”, реч је о једној конкретној енциклопедији - двотомном издању „Просветине” Мале енцииклоneдије из 1959. Ова наизглед обична и неважна књига, купљена у једном београдском антикваријату, захваљујући аутографима некадашњег власника неочекивано постаје нешто изузетно, ако не књижевно дело, онда нешто веома блиско томе:

Највећи део маргина [...] био је испуњен уредним рукописом бившег власника. [...] Коментари су се кретали од једноставног придодавања новијих биографских података неким личностима, преко вишеструког исправљања бројки у оквиру других одредница, до

\footnotetext{
${ }^{8}$ Код Павића пре свега, где се то делом очитује и у насловима његових романа и прича (,Хазардски речник”). Данило Киш је аутор „Енциклопедије мртвих”.

${ }^{9}$ Слично тумачење налазимо и овде: , ,[...] љубавна игра тече у игри речима. Изговарањем речи прелазе у свет стварности, догађају се” (Шаренац 2016. 220, подвукла В. Ц.). С. Шаренац у истом контексту на једном месту говори о специфичној функционалности речи (Шаренац 2016: 221).

${ }^{10}$ Издвајају се једино прозукли одломци и жижљиве говоранције (подвукла В. Ц.).
} 
заиста надахнутих опаски на поједина објашњења [...]. Истина, Н.Н. својим редовима није хтео или није могао да подари форму приче или романа, али је у малом чинио све што писци иначе и чине (Петровић 2004: 194-195).

Пред читаоцем је не само прича, већ буквално оваплоћење лексикографске парадигме, у правом смислу речи ${ }^{11}$. Која, како смо на неким примерима, надамо се успешно показали, несумњиво одређује једну од специфичности поетике Горана Петровића.

\section{IV. Свеобухватна парадигма зла: „Богородица и друга вићења”}

Превазилажење постмодерне поетике у смислу наглашавања стварности као оквира збивања, уз модификацију фантастичних мотива (Шаренац 2016: $499)$ и наглашен религијски подтекст карактеришу причу „Богородица и друга виђења” из збирке „Разлике”, која показује јасан отклон аутора од искључиво постмодернистичких захвата, ${ }^{12}$ уводећи на метанаративном нивоу нове повезнице са филозофијом, музиком и стварносним, и документујући тиме познату тежњу за целовитошћу наративног израза која је узроковала и форсирање енциклопедијске парадигме у књижевним текстовима овог аутора.

Ова прича не говори само о једној епизоди из ратних деведесетих и једној несвакидашњој ситуацији, већ је покушај да се објасни нешто више, наиме, сама природа зла, тако да није довољно свести све на дихотомију „вера-агностицизам” како то у критици налазимо. ${ }^{13}$ Антрополошка дубина наративног захвата очитује се у разноврсности „епизода” које илуструју дати историјски тренутак, исечак из историјске стварности деведесетих година прошлога века, свеобухватан по свом карактеру, али и деперсонализован до те мере ${ }^{14}$ да је такође оваплоћење нечега блиског лексикографској парадигми као у претходном примеру. ${ }^{15}$ Пред читаоцем је покушај да се објасни нешто што и јесте и није обично: докидање онога шта називамо нормалном свакодневницом, подизање застора који је дели од насиља и зла. Сам наслов текста је у овом контексту симптоматичан: реч је о виђењима, кратким моментима када се указује Богородица, али и о оним другим, када се питамо да ли су се то отвориле оне пукотине кроз које у овај свет доспева зло ${ }^{16}$ или су се наратору приказале, обезнаниле слике онога шта нам је већином обично скривено, слике доброте и божанског, овог другог у смислу Старог тестамента и Бога који од човека захтева жртве? На први поглед реч је о граничном феномену

${ }^{11}$ С. Шаренац упућује на постмодернистички мотив енциклопедије (Шаренац 2016: 484) и у овом контексту феномен палимпсеста (Шаренац 2016: 485, 486). По С. Шаренац „Постмодернистички мотив енциклопедије уводи у поетски круг и значење мотива Вавилонске библиотеке, али сугерише и 'отвореност' дела” (Шаренац 2016: 577).

12 Критика у томе види приближавање „традиционалној” линији српске прозе (Шаренац 2016: 586).

${ }^{13}$ Код Александра Дунђерског на пример, види Дунђерски 2010.

14 Ликови су, са изузетком оца Томе и приповедача чије презиме (Јовановић) скоро случајно сазнајемо, сви безимени.

${ }^{15}$ Мисли се на текст „На спруду”.

${ }^{16}$ Више о томе у Девите 2011, Цидилко 2016. 
чија права природа и сходно томе значај остају двојбени и загонетни. Прича почиње исказом који се управо на то односи:

Не би честито прошло месец дана, некада ни пуна седмица, а ја сам изнова виђао Богородицу. Како изричито наглашавам, не називам то указањем, већ обичним виђењем. Ко зна, можда се нешто слично збивало и раније. Кажем, можда. Али, тада сам био као и већина других, нисам је примећивао. [...] Човек је такав [...] што му је нешто ближе, толико је мање кадар да то нешто и сагледа (Петровић 2009: 121)

Уз то је реч о различитим инкарнацијама, које виђењима и самој слици Свете Деве Марије даје енциклопедијски карактер:

Богородице су се разликовале по цртама лица, по боји косе и очију, по грађи тела и покретима, по начину одевања и друштвеном положају, чак и по годинама, мада су готово све биле младе жене, тако, око тридесете (Петровић 2009: 121).

Притом се млада жена, која је прва у низу описује као икона, као уметничко дело, са атрибутима који одговарају сликарској представи:

А онда, сама та дојка, савршено бела, нежно руменог вршка, једра, као из млечног мермера у трену надахнућа Творца изведена, с горње стране скромно оперважена танким сребрним ланчићем, са привеском у облику невеликог крста... (Петровић 2009: 132-133).

Њена главна карактеристика је благост, која је не напушта:

[...] дојила је дете савршено мирна, благо осмехнута, загледана негде далеко [...]

Кад би јој благост почела чилети са лица складних црта, скретала је поглед ка детету које храни, осмех на њеним уснама би се изнова јавнуо, и она је, онако загонетна, била опет загледана негде ван свега овога. [...] Млада жена благо се осмехну детету и поче да га љуљушка [...] Жена први пут осмотри војнике. Али, благост са њеног лица не ишчезе (Петровић 2009: 132-133, 136-137).

Она је и необично обучена:

Да, тек тада сам и то приметио - носила је некакву дугачку, лагану мараму, некакав вео пребачен преко главе, али на њеном челу није било ни капље зноја (Петровић 2009: 133).

Оно шта за приповедача представља неоспорну чињеницу, за свештеника коме се обраћа је блиско богохуљењу и демонској преласти. Није случајно да аутор користи управо ову црквенословенску реч која означава обману, привиђење, али и маштарију. Маштарију која је несумњиво маркер који указује на неке од извора енциклопедијског наративног захвата овог савременог аутора.

\section{ЛИТЕРАТУРА}

Гвозденовић 2017: M. Gvozdenović, Portret među maskama. Eckermann, Web časopis za književnost, br. 11, septembar-oktobar 2017.

http://www.eckermann.org.rs7article/portret-medu-maskama 24.4.2019. 
Девите 2011: J. Dewitte, Y a-t.il une réalité substantielle du Mal? U : L. Bossi, ed. 2011. Crime et folie. Paris: Gallimard, 47-74.

Дунђерин 2010: А. Дунђерин, ГОРАН ПЕТРОВИЋ Моћно перо, а осредюа прича. 10.10.2010 http://www.pecat.co.rs/author/aleksandardundjerin 24.4.2019.

Ерколино 2016: С. Ерколино, Енциклопедијски модус у модернистичкој и постмодернистичкој прози. Поља, LXI/2016, бр. 497, 128-140.

Киш 1983: Д. Киш, Еничиклопедија мртвих, Београд.

Мецлер 2007: Metzler Lexikon Literatur 2007: Meier, Christel, Enzyklopädie, 192-193; Grimm, Gunter, Memorabile, 489.

Павић 1984: М. Павић, Хазарски речник, Београд.

Пиштало 2008: В. Пиштало, Тесла, портрет међу маскама, Београд.

Петровић 1993: Г. Петровић, Атлас описан небом, Београд.

Петровић 1996: Г. Петровић, Острво и околне приче, Београд.

Петровић 1997: Г. Петровић, Опсада иркве светог спаса, Београд.

Петровић 2003: Г. Петровић, Ближньи, Београд.

Петровић 2004: Г. Петровић, Све што знам о времену, Београд.

Петровић 2009: Г. Петровић, Разлике, Београд.

Тишма 1980: А. Тишма, Школа безбожништва, Београд.

Цидилко 2016: V. Cidilko, Aleksandar Tišma ‘s „Pentateuch”. An Attempt to Comprehend Evil, u U. Heftrich, B. Jacobs, B. Kaibach, K. Thaidigsmann (Red.), Images of Rupture between East and West. Heilderberg: Universitätsverlag Winter, 2016, 369-388.

Шаренац 2016: С. Ч. Шаренац, Поетика прозе Горана Петровића. Докторска дисертација. Универзитет у Београду, Филолошки факултет, Београд. https://nardus.mpn.gov.rs/bitstream/handle/Disertacija4066 24.4.2019.

Vesna P. Cidilko

\author{
DIE PROSA VON GORAN PETROVIĆ UND DAS \\ LEXIKOGRAPHISCH- ENYZKLOPÄDISCHES PARADIGMA \\ IN DER SERBISCHEN LITERATUR
}

\title{
(Zusammenfassung)
}

Das literarische Werk von Goran Petrović weist eine Reihe von Eigenheiten auf, die diesen zeitgenössischen Autor als Vertreter einer bestimmten literarischen Epoche der serbischen Literatur charakterisieren, aber auch seine individuellen, sehr verschiedenen Entwicklungsphasen offenlegen. Vor allem in seinen Erzählungen und essayistischen Texten finden sich Ansätze des enzyklopädischen Paradigmas als prägendes Element der narrativen Struktur. In dem Artikel wird anhand der Beispiele aus der Prosa des Autors der Versuch unternommen, einen Einblick in die Struktur von diesem narrativen Segment und seiner Funktion in den konkreten Texten zu gewinnen. 